\title{
APPLYING THE INTEGRATED PALEONTOLOGICAL SYSTEM: INTERPRETING SEQUENCE STRATIGRAPHIC ARCHITECTURE FROM MICROFOSSIL SIGNATURES. OLIGOCENE TO PLEISTOCENE SECTION. GULF OF MEXICO
}

JONES*. Garry D. Unocal Corp.. 4021 Ambassador Caffery Pkwy.. Lafayette. LA 70503, U.S.A. GARY, Anthony. Unocal Corp.. P.O. Box +551 , Houston. TX 77210, U.S.A.; and WATERS. Virginia, Unocal Corp.. P.O. Box 4551 , Houston. TX 77210, U.S.A.

The Integrated Paleontological System (IPS) is a user-friendly, interactive software application developed by Lnocal Corp. for the display and analysis of digitally-captured biostratigraphic data. IPS displays data graphically as 1) a species distribution (range) chart, and 2) a family of biostratigraphic "curves" including: diversity (Shannon-Wiener Index), total count, percent planktics, sample similarity coefficients, individual species' abundance, and specialized paleobathymetry curve. The user can easily annotate the displays and plot E-logs alongside IPS ouput. Using these multiple, interactive features speeds up data analysis and helps produce integrated solutions to geologic problems.

IPS output (based on foraminiferal and calcareous nannofossil data recovered from cuttings) was generated for dozens of Gulf of Mexico wells penetrating Oligocene-to-Pleistocene, siliciclastic sediments. The well sections represent a wide range of shallow-to deep-marine paleoenvironments. Interpretation of the IPS output was guided by published and theoretical models of microfossil response to changes in relative sea level which are assumed to be the main factor influencing sequence stratigraphic architecture. Empirical observation of IPS output indicates that changes in the microfossil record occur in predictable stratigraphic trends which can be used to enhance pre-existing response models. Integrating these enhanced models with E-log and seismic data demonstrates that IPS output can be used with confidence to characterize the key stratal surfaces which underpin the interpretation of sequence stratigraphic architecture. Flooding surfaces and sequence boundaries within the study area have the following IPS signatures:

\begin{tabular}{|l|c|c|c|c|c|c|c|c|}
\hline \multicolumn{1}{|c|}{ IPS } & $\begin{array}{c}\text { Reworked } \\
\text { Mesozoic } \\
\text { nammo- } \\
\text { fossils }\end{array}$ & $\begin{array}{c}\text { In-situ } \\
\text { nanno- } \\
\text { fossils }\end{array}$ & $\begin{array}{c}\text { Range } \\
\text { chart } \\
\text { pattern }\end{array}$ & $\begin{array}{c}\text { Total } \\
\text { foram } \\
\text { count }\end{array}$ & $\begin{array}{c}\text { Co- } \\
\text { occurring } \\
\text { foram } \\
\text { tops }\end{array}$ & $\begin{array}{c}\text { Livigerina } \\
\text { peregrina } \\
\text { count }\end{array}$ & $\begin{array}{c}\text { Similarity } \\
\text { coefficients }\end{array}$ & $\begin{array}{c}\text { Paleobathymetry } \\
\text { curve }\end{array}$ \\
\hline $\begin{array}{l}\text { FLOODING } \\
\text { SLRFACE } \\
\text { SIGNATLRE }\end{array}$ & Low & High & $\begin{array}{c}\text { Closely- } \\
\text { spaced } \\
\text { plateaus }\end{array}$ & High & High & High & $\begin{array}{c}\text { Minor } \\
\text { changes }\end{array}$ & $\begin{array}{c}\text { Deepening event, } \\
\text { often abrupt }\end{array}$ \\
\hline $\begin{array}{l}\text { SEQLENCE } \\
\text { BOLNDARY } \\
\text { SIGNATLRE }\end{array}$ & High & Low & $\begin{array}{c}\text { Base of } \\
\text { low- } \\
\text { recovery } \\
\text { interval }\end{array}$ & Low & Low & Low & $\begin{array}{c}\text { Major } \\
\text { changes }\end{array}$ & $\begin{array}{c}\text { Shallowing event } \\
\text { (basinivard shift } \\
\text { in facies) }\end{array}$ \\
\hline
\end{tabular}

The IPS paleobathymetry curve often records changes in relative sea level associated with higherorder sequences deposited over tens to hundreds of thousands of years. The paleobathymetric stacking pattern (i.e.. prograding, aggrading, backstepping) of these higher-order sequences can be used in conjunction with E-log signatures to help predict the dip orientation of sandy reservoir facies.

Routine application of IPS ouput by Unocal geoscientists working the Gulf of Mexico Basin has considerably increased their awareness that biostratigraphy is a valuable tool in the search for hydrocarbons. 